DOI:10.38136/jgon.710511

\title{
Preeklamptik ve Normotansif Gebeler Arasındaki Vimentin Seviyelerinin Karşılaştırılması
}

\section{Comparison of Vimentin Levels Between Preeclamptic and Normotensive Pregnant Women}

\author{
Emsal Pinar Topdagi YILMAZ \\ Yunus Emre TOPDAG² \\ Seda $\mathrm{ASKIN}^{3}$
}

\author{
(1) Orcid ID:0000-0001-8593-5726 \\ (1) Orcid ID:0000-0003-0656-0765 \\ (1) Orcid ID:0000-0001-6133-9065
}

\begin{abstract}
1Department of Gynecology and Obstetrics, Atatürk University School of Medicine, Erzurum, Turkey. 2Sanko University Medical Faculty Department of Obstetrics and Gynecology, Gaziantep, Turkey 3Vocational School of Health Services, Ataturk University, Erzurum, Turkey.
\end{abstract}

\section{öz}

Amaç: Gebelikte hipertansif hastalıklar dünya genelinde maternal ve perinatal mortalitenin önde gelen nedenlerinden birini oluşturur. Çalışmamııın amacı preeklampsi (PE) tanısı alan gebeler ile normal gebeler arasındaki serum vimentin seviyelerini karşılaştırmaktır.

Gereç ve Yöntemler: Kesitsel tipteki bu çalışmada 40 preeklampsi tanısı alan gebe kadın ve 21 sağıılı gebe üzerinde gerçekleştirimiştir. Maternal serum vimentin seviyeleri sandwich enzim immunoassay yöntemi ile değerlendirilmiştir.

Bulgular: Ortalama vimentin düzeyleri gruplar arasında anlamlı olarak farklı saptandı. $(47,25 \pm 29,74$ vs. $19,39 \pm 3,76 p=0,000)$ Tanı esnasındaki gebelik haftası, trombosit seviyesi, parite ve vücut kitle indeksi (VKi) açııından iki grup arasında anlamlı farklılık saptanmadı ( $p>0.05)$.

Sonuç: Bulgular vimentinin preeklampsinin patogenezinde rol oynadığını göstermektedir. Ancak hasta sayısı yüksek ve subgrupların karşılaştıııdığı daha ileri çalışmalara intiyaç vardır.

Anahtar Kelimeler: preeklampsi, vimentin, gebelik, hipertansiyon

\section{INTRODUCTION}

Preeclampsia is defined as the hypertension and end organ damage that occur after the 20th gestational week (1). Even though the incidence of preeclampsia ranges between 3-5\%, it is still an important cause of maternal and neonatal mortality or morbidity today (2). This increasing mortality and morbidity are closely correlated with the severe form of the disease that accompanies $1 \%$ of the pregnancies (3).

Although factors such as endothelial cell dysfunction, vasospasm, inflammation and oxidative stress are thought to play a role in the pathophysiology of the disease, the precise mechanism of preeclampsia is still a mystery. However, the placenta constitutes the main source in the pathophysiology of the

\section{ABSTRACT}

Abstract Background: Hypertensive diseases in pregnancy are one of the leading causes of maternal and perinatal mortality worldwide. The aim of our study to compare the serum vimentin levels between the pregnant women diagnosed with preeclampsia (PE) and the normal pregnant women.

Materials and Methods: This sectional study was conducted on 40 pregnant women diagnosed with preeclampsia and 21 healthy pregnant women. The maternal serum vimentin levels were evaluated via the sandwich enzyme immunoassay method

Results: The mean vimentin levels were found significantly different between the groups. $(47.25 \pm 29.74$ vs. $19.39 \pm 3.76 p=0.000)$ No significant difference was discovered between the two groups in respect of the gestational week, platelet level, parity and body mass index (BMI) during the diagnosis $(p>0.05)$.

Conclusion: Findings demonstrate that vimentin plays a role in the pathogenesis of preeclampsia. However, further studies, in which the number of patients is high and subgroups are compared, are needed.

Key words: preeclampsia, vimentin, pregnancy, hypertension

disease (4). Preeclampsia is assumed to occur with the mechanism resulting from the remodeling of the spiral arteries caused by angiogenic intermolecular imbalance and trophoblastic invasion disorder (5). As a result, blood flow to the placenta is disrupted and the hypoxic placenta is exposed to oxidative stress with decreasing blood flow. This oxidative stress leads to placental apoptosis (6).

Vimentin, which is a type 3 intermediate filament weighing $57000 \mathrm{KD}$, is frequently expressed in tissues (7). It plays significant physiological roles in the mechanic and structural functions of the cells. Epithelial mesenchymal transition (EMT) is an important process of trophoblast invasion. EMT, which has a critical importance in cancer metastasis, organogenesis, 
gastrulation and embryogenesis, is a process in which the phenotype of the epithelial cells changes and turns into mesenchymal cells (8). The pathology in the mesenchymal transformation causes poor invasion and poor placentation (5). Vimentin, on the other hand, is an important mesenchymal marker indicating the disappearance of the cell adhesion. This transition is the main constituent of the cytotrophoblast differentiation (9). In a normal placental tissue, trophoblastic cells undergo a transition process similar to EMT (10).

In our study, we researched the relationship between the levels of the vimentin protein in the serum fluids of preeclamptic pregnant women, whose mechanism is not known exactly, and those of the normotensive pregnant group. We researched whether vimentin could be used as an early diagnostic marker for preeclamptic pregnant women.

\section{MATERIALS AND METHODS}

Ethical approval for this prospective study was provided by the Ethical Committee of Ataturk University School of Medicine (The ethics committee approval number: B.30.2.ATA.0.01.00/235). This prospective sectional study was carried out in the perinatology department of our gynecology and obstetrics clinic. After the approval of the Local Ethics Committee of Faculty of Medicine of Atatürk University, the study was initiated. 61 pregnant patients were included in our study. Of these, 21 had normal pregnancies and 40 had preeclamptic pregnancies. The diagnosis of preeclampsia was defined as proteinuria and/or end organ damage that accompanied the presence of 140-159 $\mathrm{mmHg}$ systolic blood pressure (BP), as $\geq 140 \mathrm{mmHg}$ and/or diastolic $\mathrm{BP} \geq 90 \mathrm{mmHg}$, measured at least with 4-hour intervals in 2 conditions in the left lateral decubitus position following the 20th gestational week in a woman, who had normal blood pressure before, according to the criteria of the American College of Obstetricians and Gynecologist (ACOG) guidelines (1). Preeclamptic and normotensive pregnant women were matched in terms of age, body mass index, gestational age, laboratory findings and ultrasonographic information of the fetus. Pregnant women who had multiple pregnancies, chorioamnionitis, early membrane rupture, smoking addiction, diabetes mellitus, HELLP syndrome, chronic hypertension and multisystemic disease were not included in the study. Normal pregnant women with no medical and obstetric pathology before and during the pregnancy were included in the control group. Blood samples were collected from preeclampsia patients at the time of diagnosis before delivery. Blood samples of the control group were taken in the last trimester.
Approximately $3-5 \mathrm{ml}$ of blood samples taken from all the patients were collected in non-heparinized tubes. The serums were stored at $-80{ }^{\circ} \mathrm{C}$ until the evaluation time. The commercial kit of USCN (SEB040hHu) was used for determination of vimentin in the samples. The test principle applied in this kit is the sandwich enzyme immunoassay. All the standard, sample and biotin was added into the 96-well plate provided within the kit and coated with an antibody specific to vimentin and incubated, and then incubated again after the addition of horseradish peroxidase (HRP)-conjugated avidin; at the end of the period, the 3,3',5,5'-tetramethylbenzidine (TBM) substrate solution was added and reaction was created inside the wells, after which color change occurred. The enzyme substrate reaction was terminated with the addition of the sulfuric acid solution. The resulting color change was spectrophotometrically measured at a wavelength of $450 \mathrm{~nm}$. The Vimentin concentration in the samples was calculated according to the created standard curve graph. Statistical analysis:

The analyses were performed with IBM SPSS 20 statistical analysis program. The data were expressed as mean, standard deviation, median, minimum, maximum, percentage and number. The normal distribution of the continuous variables was investigated with the Shapiro Wilk-W test when the sample size was $<50$, and the Kolmogorov-Smirnov test when the sample size was $\geq 50$. The Independent Samples t-test was used when the condition of normal distribution was met in comparisons between two independent groups, and the Mann-Whitney $U$ test was employed when the condition was not met. The statistical significance level was accepted as $p<0.05$.

\section{RESULTS}

In total, 61 pregnant women were included in the study. Of these, 21 had normal pregnancies and 40 had preeclamptic pregnancies. Clinical, biochemical and obstetric characteristics between preeclamptic and normotensive pregnant women are shown in Table 1. No significant difference was found between the two groups in terms of the gestational week, platelet level, parity and body mass index during the diagnosis $(p>0.05)$. The gestational week and the birth weight during the birth were significantly lower in preeclamptic pregnant women when compared to the control group $(p<0.05)$. Serum aspartate aminotransferase (AST), alanine aminotransferase (ALT), systolic blood pressure and diastolic blood pressure were significantly higher in preeclamptic patients compared to the normotensive pregnant women $(p<0.01)$. Among the preeclamptic patients, no patients with HELLP syndrome was detected. 
Table 1: Clinical, biochemical and obstetric characteristics and their comparison between preeclamptic and normotensive pregnant women

\begin{tabular}{|c|c|c|c|c|c|}
\hline & \multicolumn{2}{|c|}{ Preeclamptic group } & \multicolumn{2}{|c|}{ Normotensive group } & \multirow[b]{2}{*}{$\mathrm{p}$} \\
\hline & Mean \pm std & $\begin{array}{l}\text { Median (min- } \\
\max \text { ) }\end{array}$ & Mean \pm std & $\begin{array}{l}\text { Median (min- } \\
\max \text { ) }\end{array}$ & \\
\hline Age & $28.55 \pm 4.32$ & $29(20-38)$ & $29.23 \pm 5.72$ & $30(20-40)$ & .600 \\
\hline $\begin{array}{l}\text { Diagnosis } \\
\text { week }\end{array}$ & $30.9 \pm 2.35$ & $31(25-35)$ & & & \\
\hline $\begin{array}{l}\text { Gestational } \\
\text { week }\end{array}$ & $34 \pm 2.36$ & $34.5(27-37)$ & $38.42 \pm 1.32$ & $39(36-40)$ & .000 \\
\hline Platelet $(\mu \mathrm{L})$ & $\begin{array}{c}261500 \pm \\
112883.64\end{array}$ & $\begin{array}{l}262500 \\
(50000- \\
470000)\end{array}$ & $\begin{array}{c}303952.38 \pm \\
66880.84\end{array}$ & $\begin{array}{c}280000 \\
(210000- \\
455000)\end{array}$ & .233 \\
\hline AST (U/L) & $31.87 \pm 7.89$ & $30(20-50)$ & $22.14 \pm 5.38$ & $20(15-30)$ & .000 \\
\hline $\operatorname{ALT}(\mathrm{U} / \mathrm{L})$ & $27.95 \pm 8.53$ & $25(15-55)$ & $20.09 \pm 5.43$ & $20(10-35)$ & .000 \\
\hline $\begin{array}{l}\text { Creatinine } \\
(\mathrm{mg} / \mathrm{dL})\end{array}$ & $0.68 \pm 0.24$ & $0.6(0.4-1.3)$ & $0.61 \pm 0.18$ & $0.6(0.4-1)$ & .359 \\
\hline $\begin{array}{c}\text { Birth } \\
\text { weight (g) }\end{array}$ & $\begin{array}{c}1822.75 \pm \\
461.05\end{array}$ & $\begin{array}{c}1925(700- \\
2950)\end{array}$ & $\begin{array}{c}3279.52 \pm \\
451.09\end{array}$ & $\begin{array}{c}3300(2550- \\
3900)\end{array}$ & .000 \\
\hline Parity & $2.7 \pm 1.66$ & $3(0-6)$ & $2.28 \pm 1.55$ & $2(0-6)$ & .289 \\
\hline $\begin{array}{c}\text { BMI } \\
(\mathrm{kg} / \mathrm{m} 2)\end{array}$ & $29.46 \pm 4.01$ & $\begin{array}{c}30.3(23.4- \\
36.5)\end{array}$ & $28.52 \pm 3.57$ & $30.4(22.6-35.4)$ & .589 \\
\hline $\begin{array}{c}\text { Systolic Blo- } \\
\text { od Pressure } \\
(\mathrm{mmHg})\end{array}$ & $\begin{array}{c}154.12 \pm \\
14.8\end{array}$ & $150(130-200)$ & $114.76 \pm 7.49$ & $110(100-130)$ & .000 \\
\hline $\begin{array}{l}\text { Diastolic } \\
\text { Blood } \\
\text { Pressure } \\
\text { (mmHg) }\end{array}$ & $\begin{array}{c}96.87 \pm \\
10.41\end{array}$ & $90(80-130)$ & $75.23 \pm 6.01$ & $80(60-80)$ & .000 \\
\hline $\begin{array}{l}\text { Vimentin } \\
\text { Result (ng/ } \\
\mathrm{mL} \text { ) }\end{array}$ & $\begin{array}{c}47.25 \pm \\
29.74\end{array}$ & $\begin{array}{c}37.39 \text { (16.89- } \\
173.31)\end{array}$ & $19.39 \pm 3.76$ & $\begin{array}{c}18.43(14.17- \\
25.75)\end{array}$ & .000 \\
\hline
\end{tabular}

AST = aspartate aminotransferase, ALT = alanine aminotransferase, BMl: body mass index

In preeclampsia patient group, there was no statistically significant difference in terms of vimentin levels before and after 34th gestational week. however, the level of vimentin was found to be higher under 34 weeks of gestation. When we compared the pregnant women who participated in the study before and after the 34th pregnancy week, we did not find a significant difference in terms of parameters. ( $p>0.05)$. (Table 2$)$

Table 2: Clinical, biochemical and obstetric characteristics and their comparison between before and after the 34th pregnancy week

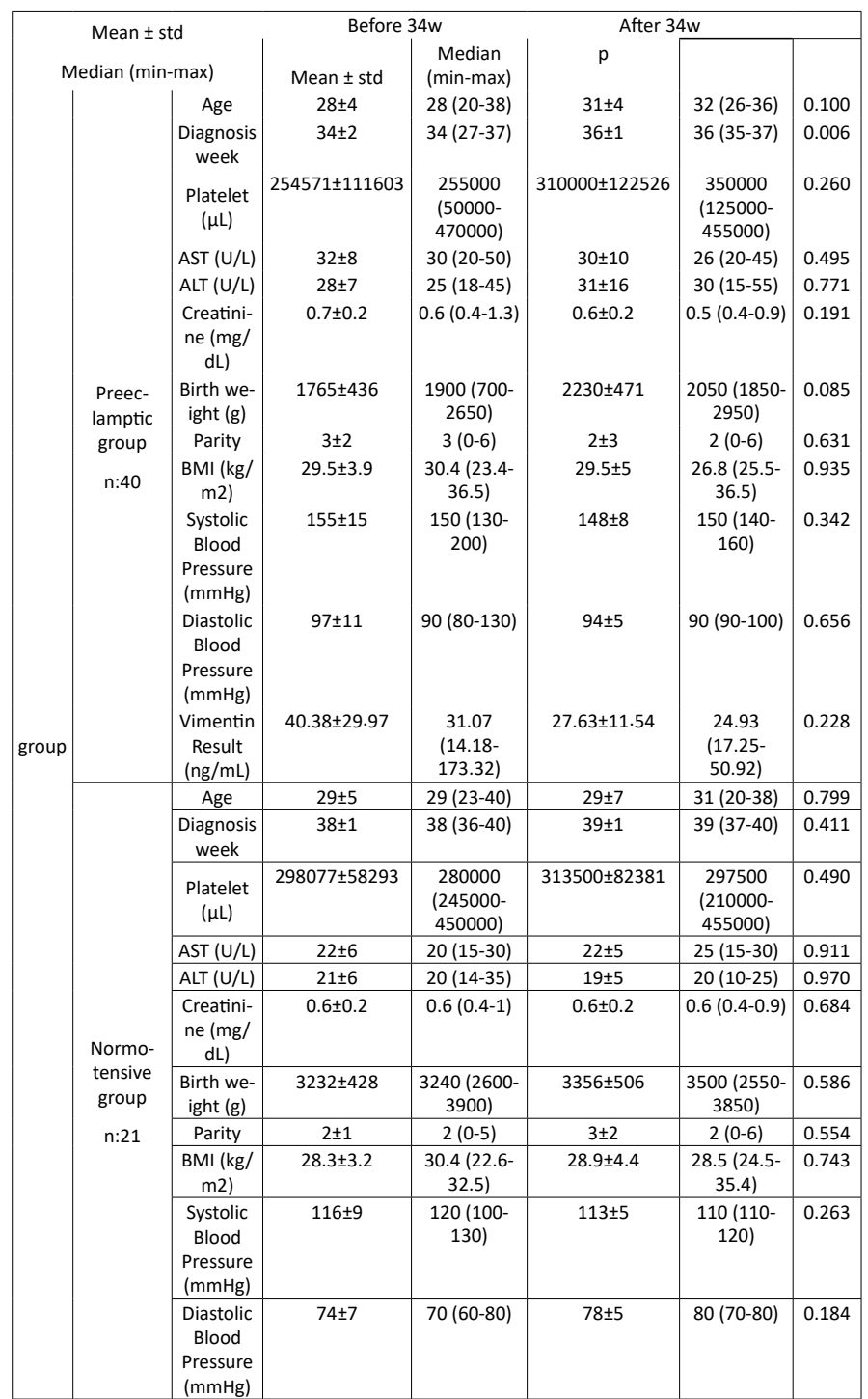

AST = aspartate aminotransferase, ALT = alanine aminotransferase, $\mathrm{BMl}$ : body mass index

The maternal serum vimentin concentration was found significantly higher in the preeclamptic patient group. $(47.25 \pm 29.74$, $19.39 \pm 3.76, p<0.01)$ (Figure 1).

Figure 1: Comparison of vimentin level between preeclamptic and normotensive pregnant women

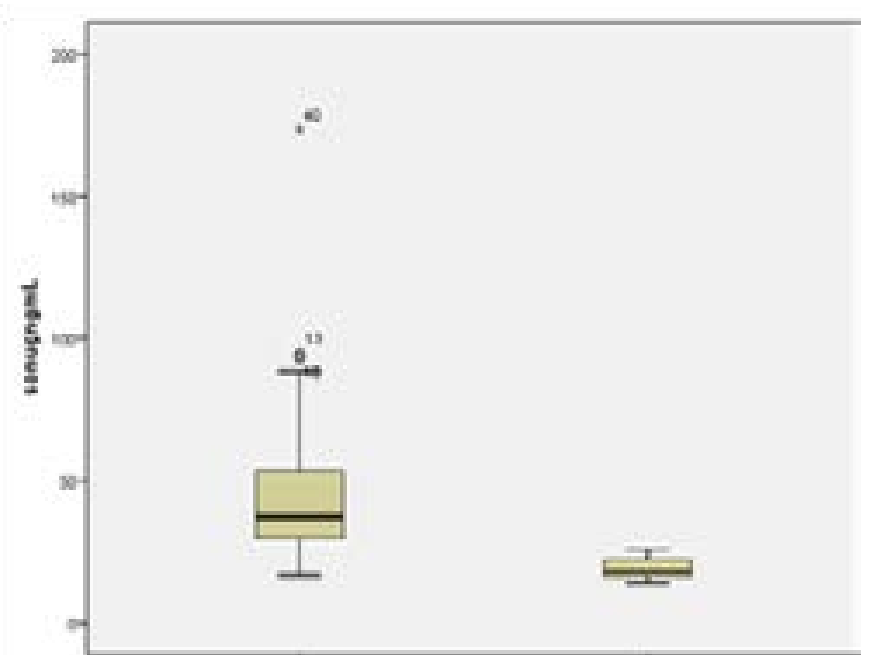




\section{DISCUSSION}

It was also discovered in our study that vimentin was significantly higher in the serum of the preeclamptic patients compared to the normotensive pregnant women. Vimentin, a mesenchymal intermediate filament protein, plays a significant role in villous contractility and fetal placental circulation. The studies have focused on finding a predictive market in preeclampsia, which constitutes an important cause of maternal and fetal mortality and morbidity.

In the study conducted by İrtegün et al., they detected an increased vimentin expression in the preeclamptic placenta11). The positive correlation between the vascular endothelial growth factor (VEGF), which is an angiogenic factor and has a significant role in trophoblastic invasion, and vimentin was shown in another study (12). In another study, it was revealed that vimentin was correlated with trophoblast invasion (13). In the pathophysiology of $\mathrm{PE}$, the primary defect is assumed to be insufficient trophoblast invasion disorder and the high-resistance spiral artery modeling it causes. This defect in vascular modeling leads to a decrease in placental perfusion. As a result, maternal endothelial dysfunction occurs together with ischemia in the placenta (14). The clarification and prediction of the placental pathophysiology and biochemical process and bio-marker determination in preeclamptic patients is necessary for the clinical care in these patients. Vimentin can be studied as a predictive marker in the prediction of preeclampsia (5). In our study, vimentin was found to be significantly higher in the serum levels of the preeclamptic patients when compared to the normal pregnant women. This increased vimentin expression is thought to decrease vascular permeability.

In another study, in the embryonic process, the vimentin expression was found to have increased in the trophoblast cells, the vascular lumen and stroma cells of the rats (15). In a study carried out by Sak et al. on patients with HELLP syndrome, an increased vimentin expression was found in the vascular lumen and stromal cells in the intravillous area (16).

The limitation of our study was the relatively low numbers of our study groups. It is known that endothelial dysfunction plays a more dominant role in the pathophysiology of the early-onset preeclampsia (1). Both early and late-onset PE cases were included in our study. We believe that studies comparing early-onset and late-onset PE with the control group will be more interesting. The increase in vimentin, a mesenchymal intermediate filament, can damage the structure of normal endothelial cells and create endothelial instability, leading to hypertension and placental dysfunction (16). In this study, we think that vimentin plays a possible role in the pathogenesis of endothelial dysfunction, however, we assert that advanced studies are needed to better clarify the underlying mechanisms.

Ethics Committee Approval: Ethics committee approval was received from the Ethics Committee of Ataturk University School of Medicine (Approval Number: B.30.2.ATA.0.01.00/235).

Conflict of Interest: No conflict of interest was declared by the authors.

Financial Disclosure: The authors declared that this study received no financial support.

\section{REFERENCES}

1. Yuksel MA, Tuten A, Oncul M, et al. Serum endocan concentration in women with pre-eclampsia. Arch Gynecol Obstet. 2015;292(1):69-73. doi:10.1007/s00404-014-3605-x

2. Akbas M, Koyuncu FM, Artunc-Ulkumen B, Taneli F, Ozdemir H. Maternal serum perlecan levels in women with preeclampsia. Hypertens Pregnancy. 2020;39(1):70-76. doi:10.10 80/10641955.2019.1711390

3. von Dadelszen P, Payne B, Li J, et al. Prediction of adverse maternal outcomes in pre-eclampsia: development and validation of the fullPIERS model. Lancet. 2011;377(9761):219227. doi:10.1016/S0140-6736(10)61351-7

4. Roberts JM, Lain KY. Recent Insights into the pathogenesis of pre-eclampsia. Placenta. 2002;23(5):359-372. doi:10.1053/plac.2002.0819

5. Mary S, Kulkarni MJ, Mehendale SS, Joshi SR, Giri AP. Differential accumulation of vimentin fragments in preeclamptic placenta. Cytoskeleton (Hoboken). 2017;74(11):420425. doi: $10.1002 / \mathrm{cm} .21390$

6. Lambert G, Brichant JF, Hartstein G, Bonhomme V, Dewandre PY. Preeclampsia: an update. Acta Anaesthesiol Belg. 2014;65(4):137-149.

7. Zergeroğlu, Sema, et al. Endometrial ve Endoservikal Adenokarsinomların Ayırıcı Tanısında Vimentin Pozitifliğinin Değeri. Türk Jinekolojik Onkoloji Dergisi 9.4: 97-100.

8. Du L, Kuang L, He F, Tang W, Sun W, Chen D. Mesenchymal-to-epithelial transition in the placental tissues of patients with preeclampsia. Hypertens Res. 2017;40(1):67-72. doi:10.1038/hr.2016.97

9. Mendez MG, Kojima S, Goldman RD. Vimentin induces changes in cell shape, motility, and adhesion during the epithelial to mesenchymal transition. FASEB J. 2010;24(6):1838- 
1851. doi:10.1096/fj.09-151639

10. Kokkinos, Maria I., et al. Cadherins in the human placenta-epithelial-mesenchymal transition (EMT) and placental development. Placenta 31.9 (2010): 747-755.

11. Irtegun $S$, Agacayak E, Deveci E. Preeklamptik ve normotansif plasentalarda VEGF ve Vimentin ekspresyon düzeylerinin immunohistokimya ve Western Blot yöntemleri ile incelenmesi. Dicle Med J 43.3 (2016): 400-405.

12. Woolf EC, Curley KL, Liu Q, et al. The Ketogenic Diet Alters the Hypoxic Response and Affects Expression of Proteins Associated with Angiogenesis, Invasive Potential and Vascular Permeability in a Mouse Glioma Model. PLoS One. 2015;10(6):e0130357. Published 2015 Jun 17. doi:10.1371/ journal.pone. 0130357

13. Shirakawa T, Miyahara Y, Tanimura K, et al. Expression of Epithelial-Mesenchymal Transition-related Factors in Adherent Placenta. Int J Gynecol Pathol. 2015;34(6):584-589. doi:10.1097/PGP.0000000000000190
14. Granger JP, Alexander BT, Llinas MT, Bennett WA, Khalil RA. Pathophysiology of hypertension during preeclampsia linking placental ischemia with endothelial dysfunction. Hypertension. 2001;38(3 Pt 2):718-722. doi:10.1161/01. hyp.38.3.718

15. Scherholz PL, de Souza PC, Spadacci-Morena DD, Katz SG. Vimentin is synthesized by mouse vascular trophoblast giant cells from embryonic day 7.5 onwards and is a characteristic factor of these cells. Placenta. 2013;34(7):518-525. doi:10.1016/j.placenta.2013.04.003

16. Sak, M. E., et al. Placental expression of vimentin, desmin and ultrastructural changes in the villi in patients with HELLP syndrome. Eur. Rev. Med. Pharmacol. Sci 17 (2013): 874-878. 